\title{
PENGARUH LEVERAGE, LIKUIDITAS, UKURAN PERUSAHAAN, DAN KUALITAS AUDIT TERHADAP KUALITAS INFORMASI LAPORAN KEUANGAN (Studi empiris pada perusahaan Properti dan Real Estate yang terdaftar di Bursa Efek Indonesia)
}

\author{
Susanti \\ Program Studi Akuntansi, Fakultas Ekonomi \\ Universitas Sarjanawiyata Tamansiswa Yogyakarta \\ E-mail: can_t7@yahoo.co.id
}

\begin{abstract}
The purpose of this study was to examine issues relating to the measurement of the quality of empirical studies of financial statement information on the company property and real estate the period 2008-2011. This study use the four independent variables, namely, leverage, liquidity, firm size, and audit quality and the use of the dependent variable as a proxy for the quality of the timeliness of financial information.

This study uses targeted Sampling (purposive sampling). Population in this research is that companies engaged in property and real estate are listed in the Indonesia Stock Exchange during the study period between 2008 to 2011 . Sample totaled 128 with 32 companies that have been based on the criteria specified. Analysis of research data using multiple linear regression with SPSS Version 16.0 .

Based on the analysis performed in this study shows that of the four proposed variables (leverage, liquidity, firm size, and quality audit) only liquidity that have a significant positive impact on the quality of financial reporting information, while leverage, firm size, and quality audit is not affect the quality of financial reporting information.
\end{abstract}

Keywords : leverage, liquidity, firm size, audit quality, timeliness .

\section{PENDAHULUAN}

Perkembangan dalam bidang perekonomian di Indonesia khususnya di pasar modal menyebabkan peranan akuntansi sebagai alat bantu dalam pengambilan keputusan ekonomi dan keuangan semakin meningkat. Akuntansi mempunyai peranan yang sangat penting dalam suatu perusahaan, kemajuan suatu perusahaan dapat dilihat dari proses akuntansi perusahaan tersebut. Akuntansi juga berfungsi sebagai sistem informasi yang menghasilkan laporan kepada pihak-pihak yang berkepentingan terhadap aktivitas ekonomi dan kondisi perusahaan.

Menurut Standar Akuntansi Keuangan No. 1 tahun 2009, laporan keuangan adalah suatu penyajian terstruktur dari posisi keuangan dan kinerja keuangan suatu entitas. Namun, secara umum menurut statement of financial accounting concept no. 2, informasi yang disajikan dalam laporan keuangan agar informasi akuntansi bermanfaat dan berkualitas harus bersifat relevance, reliability, Comparability and Consistency. Di sisi lain, informasi yang disajikan memiliki berbagai keterbatasan yang melekat di dalamnya seperti sifatnya yang umum, kuantitatif, historis, serta sarat akan taksiran (statement of financial accounting concept no.1), sehingga diharapkan dapat mengurangi munculnya manipulasi akuntansi.

Dalam era globalisasi ekonomi ini, manipulasi akuntansi mungkin untuk dilakukan dalam beberapa praktik-praktik bisnis oleh perusahaan. Skandal manipulasi melibatkan beberapa perusahaan besar yang dahulunya mempunyai kualitas audit yang tinggi di Amerika karena salah satu penyebabnya adalah rendahnya kualitas 
laporan keuangan yang dibuat. Diantaranya terjadi pada World.Com. Perusahaan AS nomor dua dalam bidang telekomunikasi ini, terlibat rekayasa keuangan milyaran dollar AS.

Pada prinsipnya pengertian kualitas laporan keuangan dapat dipandang dalam dua sudut pandang. Pandangan pertama menyatakan bahwa kualitas pelaporan keuangan berhubungan dengan kinerja keseluruhan perusahaan yang tergambarkan dalam laba perusahaan. Informasi laporan keuangan dikatakan tinggi (berkualitas) jika laba tahun berjalan dapat menjadi indikator yang baik untuk laba perusahaan di masa yang akan datang (Lev dan Thiagarajan, 1993 dalam Fanani 2009). Pandangan kedua menyatakan bahwa kualitas pelaporan keuangan berkaitan dengan kinerja saham perusahaan di pasar modal yang diwujudkan dalam bentuk imbalan saham (Fanani, 2009). Hal ini sejalan dengan perkembangannya akan menuntut perusahaan publik menjalankan sistem manajemennya secara baik, transparan dan akuntabel, karena semakin maraknya perusahaan yang mencoba berbagai hal untuk melakukan kecurangan pelaporan kepada pihak publik (Prena, 2012).

Menurut penelitian terdahulu, penelitian kualitas laporan keuangan dapat dilakukan dengan dua pendekatan (Pagalung, 2006 dalam Fanani, 2009). pendekatan ini berkaitan dengan faktor-faktor internal perusahaan. Faktor tersebut antara lain terdiri dari siklus operasi, volalitas penjualan, ukuran perusahaan, umur perusahaan, proporsi kerugian, leverage, likuiditas, klasifikasi industri, kepemilikan manajerial, kepemilikan institusional, konsentrasi pasar, kualitas audit, dan pertumbuhan investasi. Pendekatan kedua berkaitan dengan faktor eksternal yang merupakan respons pemakai informasi pelaporan keuangan, yaitu sejauh mana informasi laporan keuangan direspon oleh para pemakai.

Francis et al. 2004 dalam Indriani (2010) membagi dua kelompok besar atribut kualitas pelaporan keuangan, yaitu atributatribut berbasis akuntansi dan berbasis pasar.
Atribut kualitas pelaporan keuangan berbasis akuntansi adalah kualitas akrual, persistensi, prediktabilita, dan perataan laba. Sedangkan untuk atribut kualitas pelaporan keuangan berbasis pasar terdiri dari relevansi nilai, ketepatwaktuan, dan konservatisme.

Motivasi penelitian ini adalah untuk mengkaji isu-isu yang berkaitan dengan pengukuran kualitas informasi laporan keuangan. Penelitian ini menggunakan ketepatwaktuan sebagai proksi kualitas informasi keuangan. Dalam penelitian Suriadi (2009) menjelaskan bahwa laporan keuangan sebagai sebuah informasi yang akan bermanfaat apabila informasi yang dikandungnya disediakan tepat waktu bagi pembuat keputusan sebelum informasi tersebut kehilangan kemampuannya dalam mempengaruhi pengambilan keputusan. Jika terdapat penundaan yang tidak semestinya dalam pelaporan, maka informasi yang dihasilkan akan kehilangan relevansinya. Ketepatwaktuan (timelines) salah satu kriteria pendukung dari sifat relevan, secara normatif dapat dimiliki oleh informasi keuangan sebagai salah satu kriteria karakteristik kualitatif laporan keuangan.

Fokus penelitian ini berkaitan dengan faktor internal perusahaan yang berkaitan dengan faktor inheren atau intrinsik yang melekat di perusahaan itu sendiri. Faktor tersebut adalah faktor statis (ukuran perusahaan), faktor risiko institusi (leverage, likuiditas) (Fanani, 2009), dan kualitas audit sebagai variabel tambahan untuk memperkuat penelitian.

Leverage merupakan alat untuk mengukur seberapa jauh suatu perusahaan bergantung pada kreditor dalam membiayai aset perusahaan. Perusahaan yang mempunyai leverage yang tinggi berarti sangat bergantung pada pinjaman luar untuk membiayai asetnya, sedangkan perusahaan yang mempunyai leverage rendah lebih banyak membiayai asetnya dengan modal sendiri (Sulistyo, 2010). Sehingga besarnya leverage perusahaan akan menyebabkan perusahaan akan meningkatkan kualitas laporan keuangan dengan tujuan untuk 
mempertahankan kinerja yang baik di mata investor dan kreditor.

Likuiditas adalah ketersediaan sumber daya (kemampuan) perusahaan untuk memenuhi kewajiban jangka pendeknya yang telah jatuh tempo, dengan melihat aset lancar perusahaan relatif terhadap hutang lancarnya (Sulistyo, 2010). Perusahaan yang yang memiliki tingkat likuiditas yang tinggi menunjukkan bahwa perusahaan tersebut memiliki kemampuan yang tinggi dalam melunasi kewajiban jangka pendeknya. Hal ini merupakan berita baik sehingga perusahaan dengan kondisi seperti ini cenderung berusaha meningkatkan kualitas laporan keuangan. Karena likuiditas juga sangat erat hubungannya dengan kreditur, jika kondisi perusahaan tidak likuid berarti akan terjadi penundaan pengumpulan bunga dan pokok pinjaman yang diberikan sehingga kreditur akan mempertimbangkan dengan matang perusahaan mana yang akan ia berikan kredit agar tidak mengalami kerugian (Fanani, Ningsih dan Hamidah, 2009).

Besar kecilnya perusahaan (ukuran perusahaan) dapat mempengaruhi kemampuan manajemen untuk mengoperasikan perusahaan dengan berbagai situasi dan kondisi yang dihadapinya. Secara teoritis, perusahaan yang lebih besar biasannya memiliki kepastian (certainty) dan tingkat return yang lebih besar pula daripada perusahaan yang relatif kecil sehingga mengurangi ketidakpastian atau risiko mengenai prospek perusahaan ke depan, sehingga hal tersebut dapat membantu para investor dalam memprediksi risiko yang mungkin akan terjadi jika investor berinvestasi pada perusahaan. Dengan demikian, semakin besar ukuran perusahaan maka perusahaan akan semakin transparan dan akuntabel dalam meningkatkan kualitas laporan keuangannya kepada publik (Fajri, 2013).

Pengguna informasi laporan keuangan akan mempertimbangkan pendapat audit sebelum menggunakan informasi tersebut sebagai dasar dalam pengambilan keputusan ekonomis. Penelitian Fanani,
Ningsih dan Hamidah (2009) menjelaskan bahwa auditor skala besar lebih cenderung untuk mengungkapkan masalah-masalah yang ada karena mereka lebih kuat menghadapi risiko proses pengadilan. Argumen tersebut berarti bahwa auditor skala besar memiliki insentif lebih untuk mendeteksi dan melaporkan masalah kliennya dan lebih memungkinkan mendeteksi praktik-praktik akuntansi yang masih diragukan. Berdasarkan latar belakang diatas maka penelitian ini mengambil judul "Pengaruh Leverage, Likuiditas, Ukuran Perusahaan, dan Kualitas Audit Terhadap Kualitas Informasi Laporan Keuangan (Studi Empiris pada Perusahaan Properti dan Real Estate yang terdaftar di Bursa Efek Indonesia periode 2008-2011)".

\section{KAJIAN TEORI \\ Laporan Keuangan}

Kieso (2008) mendefinisikan laporan keuangan sebagai sarana pengomunikasian informasi keuangan utama kepada pihakpihak di luar perusahaan. Laporan ini menampilkan sejarah perusahaan yang dikuantifikasi dalam nilai moneter.

\section{Kualitas laporan keuangan}

Ratih (2010) dalam Fajri (2013) mendefinisikan kualitas laporan keuangan adalah apabila informasi yang disajikan dalam laporan keuangan tersebut dapat dipahami, dan memenuhi kebutuhan pemakainya dalam pengambilan keputusan, bebas dari pengertian yang menyesatkan, kesalahan material serta dapat diandalkan, sehingga laporan keuangan tersebut dapat dibandingkan dengan periode-periode sebelumnya.

\section{Likuiditas}

Likuiditas (liquidity) mengacu pada kemampuan perusahaan untuk memenuhi kewajiban jangka pendeknya. Likuiditas merupakan kemampuan untuk mengubah aktiva menjadi kas atau kemampuan untuk memperoleh kas. Perusahaan yang yang memiliki tingkat likuiditas yang tinggi menunjukkan bahwa perusahaan tersebut 
memiliki kemampuan yang tinggi dalam melunasi kewajiban jangka pendeknya. Hal ini merupakan berita baik sehingga perusahaan dengan kondisi seperti ini cenderung berusaha meningkatkan kualitas laporan keuangan.

\section{Leverage}

Leverage keuangan mengacu pada jumlah pendanaan utang (yang memberikan pengembalian tetap) dalam struktur modal perusahaan. Besarnya leverage perusahaan akan menyebabkan perusahaan meningkatkan kualitas pelaporan keuangan dengan tujuan untuk mempertahankan kinerja yang baik di mata investor dan kreditor. Dengan kinerja yang baik tersebut diharapkan kreditor tetap memiki kepercayaan terhadap perusahaan, tetap mudah mengucurkan dana, dan kreditor akan memperoleh informasi kemampuan pembayaran (Fanani, 2009).

\section{Ukuran Perusahaan}

Ukuran perusahaan menunjukkan besar kecilnya perusahaan yang dapat dilihat dari tingkat penjualan, jumlah tenaga kerja atau jumlah aktiva yang dimiliki perusahaan (Sulistyawati, 2010). Semakin besar total aktiva, maka semakin banyak modal yang ditanam oleh para investor terhadap perusahaan. Perusahaan yang memiliki total aktiva besar menunjukkan bahwa perusahaan tersebut telah mencapai tahap kedewasaan dimana dalam tahap ini arus kas perusahaan sudah positif dan dianggap memiliki prospek yang baik dalam jangka waktu yang relatif lama, selain itu juga mencerminkan bahwa perusahaan relatif lebih stabil dan lebih mampu menghasilkan laba dibanding perusahaan dengan total aset kecil (Adiwiratama, 2012). Selain itu, semakin besar ukuran perusahaan maka perusahaan akan semakin transparan dan akuntabel dalam meningkatkan kualitas laporan keuangannya kepada publik.

\section{Kualitas Audit}

Penelitian Fanani, Ningsih dan Hamida (2009) menjelaskan bahwa auditor skala besar lebih cenderung untuk mengungkapkan masalah-masalah yang ada karena mereka lebih kuat menghadapi risiko proses pengadilan. Argumen tersebut berarti bahwa auditor skala besar memiliki insentif lebih untuk mendeteksi dan melaporkan masalah kliennya dan lebih memungkinkan mendeteksi praktik-praktik akuntansi yang masih diragukan. Kualitas audit meningkat dengan ukuran KAP karena KAP besar mempunyai kemampuan lebih untuk berspesialisasi dan berinovasi melalui teknologi sehingga meningkatkan kemungkinan KAP besar untuk menemukan pelanggaran dalam sistem akuntansi perusahaan.

\section{METODE PENELITIAN Sifat penelitian}

Penelitian ini menggunakan pendekatan kuantitatif dengan hypothesis testing. Jenis studi hypothesis testing, menjelaskan karakteristik dari suatu hubungan atau menentukan perbedaan diantara dua kelompok variabel pada situasi tertentu. Biasanya studi yang dilakukan akan terdiri dari studi beda, studi pengaruh dan studi hubungan diantara variabel-variabel tertentu (Efferin, 2008:63). Dalam hal ini pengaruh dan hubungan antara variabel independen (leverage, likuiditas, ukuran perusahaan, dan kualitas audit) dengan variabel dependen (kualitas informasi laporan keuangan).

\section{Variabel Penelitian}

Adapun variabel independen dalam penelitian ini yaitu leverage, likuiditas, ukuran perusahaan, dan kualitas audit. Sedangkan variabel dependen dalam penelitian ini adalah kualitas informasi laporan keuangan yang diproksikan dengan ketepatwaktuan.

\section{Pengukuran Variabel}

Pengukuran variabel yang digunakan dalam penelitian ini adalah sebagai berikut:

1) Variabel bebas atau independent variable, terdiri dari: 
a) Leverage (X1) diproksikan dengan Debt Ratio yaitu perbandingan antara total kewajiban dengan total asset yang dinyatakan dengan rumus:

$$
\text { Debt Ratio }=\frac{\text { Total Liabilitas }}{\text { Total Aset }}
$$

b) Likuiditas (X2) dinyatakan dengan rumus:

Rasio lancar $=\frac{\text { aktiva lancar }}{\text { kewajiban lancar }}$

c) Ukuran perusahaan (X3) dinyatakan dengan besarnya total asset perusahaan, dengan rumus:

$$
U P=\text { Ln Total Aset }
$$

d) Kualitas audit (X4) dinyatakan dengan rumus: Dalam penelitian ini, kualitas audit diukur dengan KAP Big 4 versus KAP non-Big 4. Dummy 1 untuk auditor yang tergabung dalam skala besar (Big Four) dan 0 untuk auditor yang lain.

2) Variabel terikat atau Dependent Variable yaitu:

a) Kualitas informasi laporan keuangan Dalam penelitian ini kualitas informasi laporan keuangan diproksikan dengan ketepatwaktuan yang diukur dengan skema order nilai negatif dari adjusted $R 2$ regresi reversal, yang menggunakan laba sebagai variabel dependen dan ukuran return sebagai variabel independen (Ramadhan, 2011) dapat dirumuskan sebagai berikut:

Earnings $_{j t}=\beta_{0}+\beta_{1} \mathrm{NE}+\beta_{2} \mathrm{RET}_{\mathrm{jt}}+\varepsilon_{\mathrm{jt}}$

Dimana:

Earning $_{j t}=$ Laba bersih sebelum pos-pos luar biasa perusahaan $\mathrm{j}$ tahun t.

NEGjt = Dummy variabel, 1 jika RETjt $<1$ dan 0 untuk yang lain.

RETjt $=$ Return rata-rata selama 15 bulan (bulan januari tahun $\mathrm{t}$ sampai maret tahun $\mathrm{t}+1$ ) perusahaan $\mathrm{j}$ tahun $\mathrm{t}$

\section{Populasi dan Sampel}

Populasi dalam penelitian ini adalah perusahaan properti dan real estate yang terdaftar di Bursa Efek Indonesia selama periode penelitian yaitu antara tahun 2008 sampai dengan tahun 2011. Sampel berjumlah 128 dengan 32 perusahaan yang dipilih dengan menggunakan penyampelan bersasaran (purposive sampling).

\section{Prosedur pemilihan sampel dalam penelitian ini adalah sebagai berikut:}

\begin{tabular}{|c|l|l|}
\hline $\begin{array}{l}\text { Perusahaan dalam industri Properti dan Real Estate yang } \\
\text { sudah } \begin{array}{l}\text { go public atau listing di Bursa Efek Indonesia untuk } \\
\text { periode 2008-2011 secara berturut-turut }\end{array}\end{array}$ & 1 \\
\hline $\begin{array}{l}\text { Perusahaan yang tidak menerbitkan laporan keuangan } \\
\text { tahunan yang dinyatakan dengan dalam rupiah (Rp) } \\
\text { selama 4 tahun berturut-turut periode 2008-2011. }\end{array}$ & $5)$ \\
\hline $\begin{array}{l}\text { Perusahaan yang tidak menerbitkan laporan keuangan } \\
\text { secara lengkap }\end{array}$ & $14)$ \\
\hline $\begin{array}{l}\text { Perusahaan yang tidak menyertakan nama auditor dari } \\
\text { KAP Big four maupun non-Big four }\end{array}$ & $0)$ \\
\hline Jumlah Sampel Perusahaan Properti dan Real Estate & 2 \\
\hline
\end{tabular}

\section{Sumber dan Metode Pengumpulan Data Jenis data}

Data yang digunakan dalam penelitian ini berupa data sekunder yaitu data yang diperoleh secara tidak langsung dari sumber utama (perusahaan) yang digunakan sebagai objek penelitian. Data tersebut adalah laporan keuangan tahunan (annual report) 
perusahaan-perusahaan yang tergolong dalam industri Properti dan Real Estate selama periode tahun 2008-2011.

\section{Sumber Data}

Perusahaan-perusahaan yang tergolong dalam industri Properti dan Real Estate selama periode tahun 2008-2011. yang diperoleh dari Pojok Bursa Efek Indonesia FE UST yang berupa laporan keuangan dan laporan tahunan yang dikeluarkan perusahaan-perusahaan go public yang terdaftar di Bursa Efek Indonesia dan annual report Indonesian Capital Market Directory (ICMD).

\section{Metode Analisis Data}

Metode analisis data yang digunakan pada penelitian ini adalah regresi berganda. Dalam penelitian ini adalah untuk mengetahui ada tidaknya pengaruh leverage, likuiditas, ukuran perusahaan dan kualitas audit sebagai variabel bebas (independent variable) terhadap kualitas informasi laporan keuangan sebagai variabel terikat (dependent variable).

Pembuktian terhadap hipotesis dalam penelitian ini menggunakan regresi berganda dengan 4 variabel bebas sebagai berikut:

Keterangan:

$$
F R Q=\alpha+\beta_{1} \mathrm{LEV}+\beta_{2} \mathrm{LIK}+\beta_{3} \mathrm{SIZE}+\beta_{4} \mathrm{KA}+\varepsilon
$$

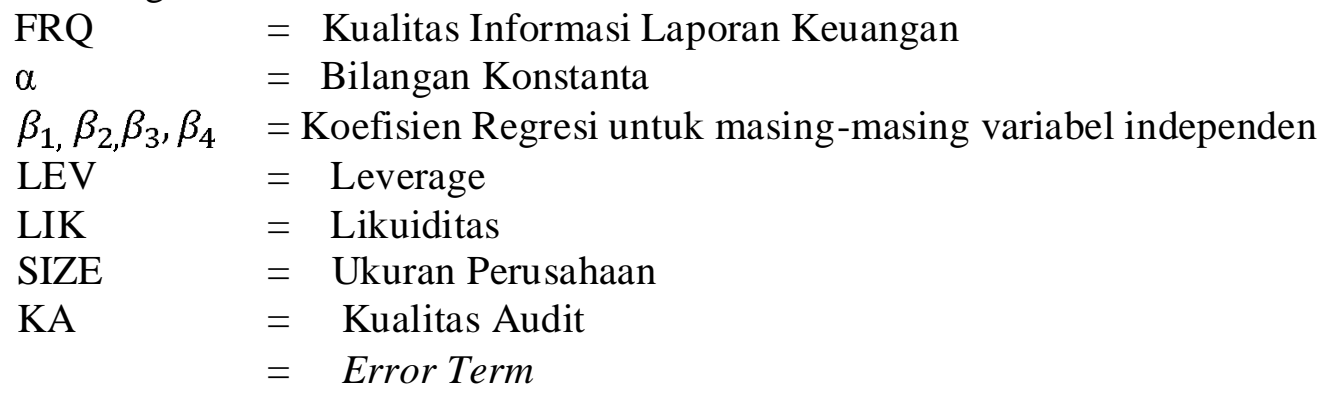

\section{ANALISA DAN PEMBAHASAN}

Berdasarkan hasil pemilihan sampel dengan menggunakan metode purposive sampling atas populasi penelitian, diperoleh sebanyak 32 perusahaan properti dan real estate yang telah terdaftar di Bursa Efek Indonesia untuk periode 2008-2011 (4 tahun) sebanyak 128 sampel.

\section{Analisis Uji Asumsi Klasik Uji Multikolinieritas}

Menguji apakah pada model regresi ditemukan adanya korelasi antar variabel independen. Pada kolom Collinearity Statistics, nilai VIF untuk leverage sebesar 1.037, likuiditas sebesar 1.043, ukuran perusahaan sebesar 1.055, dan kualitas audit sebesar 1.057. Keempat variabel independen mempunyai angka VIF ada di sekitar angka kurang dari 10, dengan demikian dapat disimpulkan bahwa penelitian tersebut bebas dari multikolinieritas.

\section{Uji Autokorelasi}

Menguji apakah dalam sebuah model regresi linier ada korelasi antara kesalahan pengganggu pada periode $t$ dengan kesalahan pada periode t-1 Dari tabel hasil uji autokorelasi diketahui bahwa nilai Durbin Watson sebesar 0.901. Angka tersebut berada di kisaran -2 sampai +2. Oleh karena itu, dapat disimpulkan bahwa dalam penelitian ini tidak terjadi autokorelasi.

\section{Uji Heteroskedastisitas}

Menurut Udayana (2008), Uji Heteroskedastisitas digunakan untuk menguji apakah dalam sebuah model regresi, terjadi ketidaksamaan varian residual dari satu pengamatan ke pengamatan yang lain. Adapun untuk mendeteksi digunakan uji glejser dengan cara meregres seluruh variabel independen dengan nilai absolute residual (absolut) sebagai variabel dependennya Dari gambar yang sudah diuji ada titik-titik menyebar secara acak, tidak 
membentuk sebuah pola tertentu yang jelas, serta tersebar baik di atas maupun di bawah angka 0 pada sumbu Y. Hal ini berarti tidak terjadi heteroskidastisitas pada model regresi, sehingga model regresi layak dipakai untuk prediksi kualitas informasi laporan keuangan berdasarkan masukan leverage, likuiditas, ukuran perusahaan, dan kualitas audit.

\section{Uji Normalitas}

Menguji apakah dalam sebuah model regresi, variabel dependen, variabel independent atau keduanya mempunyai distribusi normal ataukah tidak.

Berdasarkan Gambar P-P plot standardized residual menunjukkan pola data terdistribusi normal, terlihat titik-titik menyebar disekitar garis diagonal dan mengikuti arah garis diagonal, maka model regresi memenuhi persamaan normalitas.

\section{Analisis Regresi}

Persamaan regresi yang diperoleh dalam penelitian ini adalah sebagai berikut:

$\mathrm{Y}=0.608-0.004 \mathrm{LEV}+0.048 \mathrm{LIK}+$ $0.017 \mathrm{UP}-0.190 \mathrm{KA}$

Dari persamaan diatas diketahui nilai konstanta sebesar 0.608 menyatakan bahwa jika leverage diasumsikan bernilai nol (LEV=0), likuiditas bernilai nol $(\mathrm{LIK}=0)$, Ukuran perusahaan $(\mathrm{UP}=0)$, dan kualitas audit $(\mathrm{KA}=0)$ maka nilai kualitas informasi laporan keuangan sebesar 0.608. Leverage mempunyai nilai koefisien regresi sebesar 0.004 menyatakan bahwa setiap penambahan $1 \%$ leverage (dengan asumsi nilai koefisien variabel lain tetap dan tidak berubah) maka akan menurunkan kualitas informasi laporan keuangan sebesar 0.004. Namun sebaliknya jika leverage mengalami penurunan sebesar $1 \%$, maka kualitas informasi laporan keuangan diprediksi mengalami peningkatan sebesar 0.004 .

Likuiditas mempunyai nilai koefisien regresi sebesar 0.048 menyatakan bahwa setiap penambahan 1\% likuiditas (dengan asumsi nilai koefisien variabel lain tetap dan tidak berubah) maka akan meningkatkan kualitas informasi laporan keuangan sebesar
0.048. Namun sebaliknya jika likuiditas mengalami penurunan sebesar $1 \%$, maka kualitas informasi laporan keuangan diprediksi mengalami penurunan sebesar 0.048 .

Ukuran perusahaan mempunyai nilai koefisien regresi sebesar 0.017 menyatakan bahwa setiap penambahan $1 \%$ ukuran perusahaan (dengan asumsi nilai koefisien variabel lain tetap dan tidak berubah) maka akan meningkatkan kualitas informasi laporan keuangan sebesar 0.017. Namun sebaliknya jika ukuran perusahaan mengalami penurunan sebesar $1 \%$, maka kualitas informasi laporan keuangan diprediksi mengalami penurunan sebesar 0.017 .

Kualitas Audit mempunyai nilai koefisien regresi sebesar -0.190 menyatakan bahwa setiap penambahan $1 \%$ kualitas audit (dengan asumsi nilai koefisien variabel lain tetap dan tidak berubah) maka akan menurunkan kualitas informasi laporan keuangan sebesar 0.190. Namun sebaliknya jika kualitas audit mengalami penurunan sebesar $1 \%$, maka kualitas informasi laporan keuangan diprediksi mengalami peningkatan sebesar 0.190 .

\section{Uji individu atau parsial (uji-t)}

Leverage mempunyai nilai $t_{\text {hitung }}$ sebesar -3.649 sedangkan $t_{\text {tabel }}$ sebesar 1,979439 sehingga $t_{\text {hitung }}<t_{\text {tabel }}$ dengan probabilitas signifikansi untuk variabel leverage 0.000 lebih kecil dari taraf signifikansi 0.05. Berdasarkan hal ini maka $H_{o 1}$ diterima dan $H_{a 1}$ ditolak, sehingga dapat disimpulkan bahwa secara parsial leverage mempunyai pengaruh tidak signifikan terhadap kualitas informasi laporan keuangan.

Likuiditas mempunyai nilai $t_{\text {hitung }}$ sebesar 10.308 sedangkan $t_{\text {tabel }}$ sebesar 1,979439 sehingga $t_{\text {hitung }}>t_{t}$ dengan probabilitas signifikansi untuk variabel leverage 0.000 lebih kecil dari taraf signifikansi 0.05 . likuiditas mempunyai pengaruh positif terhadap kualitas informasi laporan keuangan. 
Ukuran perusahaan mempunyai nilai $t_{\text {hitung }}$ sebesar 0.182 sedangkan $t_{\text {tabel }}$ sebesar 1,979439 sehingga $t_{\text {hitung }}<t_{\text {tabel }}$ dengan probabilitas signifikansi untuk variabel ukuran perusahaan 0.856 lebih besar dari taraf signifikansi 0.05. Sehingga ukuran perusahaan berpengaruh terhadap kualitas informasi laporan keuangan.

Kualitas Audit mempunyai nilai $t_{\text {hitung }}$ sebesar -0.742 sedangkan $t_{\text {tabel }}$ sebesar 1,979439 sehingga $t_{\text {hitung }}<t_{\text {tabel }}$ dengan probabilitas signifikansi untuk variabel kualitas audit 0.459 lebih besar dari taraf signifikansi 0.05 . sehingga kualitas audit tidak berpengaruh terhadap kualitas informasi laporan keuangan.

Dari uji ANOVA (Analysis of Variance) atau Uji F menunjukkan bahwa nilai $F_{\text {hitung }}$ sebesar 28.490 sedangkan $F_{\text {tabel }}$ sebesar 2.445368 dengan Degree of Fredoom pembilang $=4$, Degree of Fredoom penyebut $=123$ dan taraf signifikan $\alpha=0.05$ sehingga $F_{\text {hitung }}>F_{\text {tabel }}$. Pada tabel yang sama dapat dilihat bahwa nilai $\alpha=0.000$ lebih kecil dari lebih kecil dari taraf signifikansi yang ditentukan yaitu $\alpha=0.05$. dengan demikian maka Ho ditolak dan $\mathrm{Ha}$ diterima, sehingga dapat disimpulkan bahwa leverage, likuiditas, ukuran perusahaan, dan kualitas audit secara simultan berpengaruh terhadap kualitas informasi laporan keuangan.

\section{Pengujian Koefisien Determinasi}

Hasil pengujian koefisien determinasi diketahui bahwa nilai adjusted $\mathrm{R}$ sebesar 0.464 yang berarti bahwa $46.4 \%$ kualitas informasi laporan keuangan dipengaruhi oleh leverage, likuiditas, ukuran perusahaan dan kualitas audit, sedangkan sisanya $53.6 \%$ kemungkinan dipengaruhi oleh variabel lain diluar penelitian ini.

\section{Pembahasan}

Berdasarkan analisis yang telah dilakukan diperoleh nilai $F_{\text {hitung }}>F_{\text {tabel }}$ $(28.490>2.445368)$ dengan nilai $\alpha=0.000<$ 0.05 , sehingga dapat disimpulkan bahwa leverage, likuiditas, ukuran perusahaan, dan kualitas audit secara simultan berpengaruh terhadap kualitas informasi laporan keuangan pada perusahaan properti dan real estate periode 2008-2011.

Hasil uji hipotesis secara individu menunjukkan bahwa nilai $\mathrm{t}$ hitung untuk variabel leverage (X1) terhadap kualitas informasi laporan keuangan (Y) sebesar 3.649 dan $\mathrm{t}$ tabel sebesar 1,979439 $\left(t_{\text {hitung }}<t_{\text {tabel }}\right)$ dengan probabilitas signifikansi untuk variabel leverage 0.000 lebih kecil dari taraf signifikansi 0.05 , dengan demikian leverage tidak mempunyai pengaruh yang signifikan terhadap kualitas informasi laporan keuangan. Hasil temuan ini tidak sama dengan penelitian Fanani, Ningsih dan Hamidah (2008) tetapi mendukung penelitian Ramadhan (2011) dan Fanani (2009). Perusahaan yang mempunyai leverage tinggi berarti keberlangsungan operasinya bergantung pada pembiayaan luar untuk membiayai aset, sedangkan perusahaan yang mempunyai leverage rendah lebih banyak membiayai investasinya dengan modal sendiri (Ramadhan, 2011). Besarnya leverage perusahaan akan menyebabkan perusahaan meningkatkan kualitas laporan keuangannya dengan tujuan untuk mempertahankan kinerja yang baik di mata investor dan kreditor, namun tidak semua perusahaan mampu melakukan aktivitas ini karena sangat tergantung pada kredibilitas perusahaan (Fanani, 2009). Secara empiris perusahaan properti dan real estate untuk periode 2008-2011, terbukti belum dapat memanfaatkan leverage untuk dapat meningkatkan kualitas laporan keuangan.

Likuiditas adalah kemampuan perusahaan untuk memenuhi kewajiban jangka pendeknya. Hasil penelitian ini menunjukkan bahwa likuiditas secara signifikan mempengaruhi kualitas informasi laporan keuangan. Koefisien yang dihasilkan sebesar 10.308 ( $t_{\text {hitung }}$ ) dengan probabilitas sebesar 0.000. Hasil ini membuktikan bahwa $H$ ditolak. Hasil penelitian berbeda dengan penelitian Fanani, Ningsih dan Hamidah (2009). Likuiditas sangat erat kaitannya dengan kreditur, karena jika kondisi 
perusahaan tidak likuid berarti akan terjadi penundaan pengumpulan bunga dan pokok pinjaman yang diberikan. Akibatnya kreditur akan mempertimbangkan dengan matang perusahaan mana yang akan diberikan kredit agar tidak mengalami kerugian (Fanani, 2009). Dengan kondisi yang seperti itu, perusahaan akan lebih hati-hati dan berusaha meningkatkan kualitas laporan keungan untuk mempertahankan kinerja yang baik di mata kreditor.

Ukuran perusahaan adalah skala besarnya perusahaan. Hasil penelitian ini menunjukkan bahwa ukuran perusahaan tidak berpengaruh terhadap kualitas informasi laporan keuangan. Koefisien yang dihasilkan sebesar 0.182 sedangkan $t_{\text {tabel }}$ sebesar 1,979439 sehingga $t_{\text {hitung }}<t_{\text {tabel }}$ dengan probabilitas signifikansi sebesar 0.856. Hasil penelitian ini sejalan dengan penelitian Fanani (2009) dan Fanani, Ningsih dan Hamidah (2009) namun bertentangan dengan penelitian yang dilakukan oleh Fajri (2013) dan Ramadhan (2011). Ukuran perusahaan merupakan faktor innate yang statis, dimana ukuran ini dapat mempengaruhi kualitas laporan keuangan (Fanani, 2009). Perusahaan yang besar akan memiliki kestabilan dan operasi yang dapat diprediksi lebih baik, sehingga kesalahan estimasi yang ditimbulkan akan menjadi lebih kecil. Selain itu, perusahaan besar akan memiliki kemampuan diversifikasi yang lebih baik dan mempunyai efek variasi portofolio antar divisi-divisi dan aktivitas bisnisnya sehingga dapat mengurangi efek relatif kesalahan estimasi. Meskipun demikian, perusahaan besar akan banyak menghadapi sensitivitas politik yang tinggi dan menghadapi kos politikal yang lebih tinggi dari pada perusahaan kecil (Gu et al. 2002 dalam Fajri 2013).

Kualitas audit diukur dengan skala ukuran KAP Big four versus KAP non Big four. Dummy 1 untuk auditor yang tergabung dalam skala besar (Big Four) dan 0 untuk auditor yang lain. Hasil penelitian menunjukkan bahwa kualitas audittidak berpengaruh terhadap kualitas informasi laporan keuangan. Koefisien yang dihasilkan sebesar -0.742 sedangkan $t_{\text {tabel }}$ sebesar 1,979439 sehingga $t_{\text {hitung }}<t_{\text {tabel }}$ dengan probabilitas signifikansi sebesar 0.459 . penelitian ini bertentangan dengan penelitian yang dilakukan oleh Fanani, Ningsih dan Hamidah (2009). KAP besar mempunyai kemampuan yang lebih besar untuk mengaudit lebih akurat karena mereka memiliki lebih banyak hubungan spesifik dengan klien yang akan hilang jika mereka memberikan laporan yang tidak akurat. Selain itu karena KAP besar memiliki sumber daya atau kekayaan yang lebih besar daripada KAP kecil, maka mereka terancam oleh tuntutan hukum pihak ketiga yang lebih besar pula bila mereka tidak menghasilkan laporan audit yang tidak akurat (Putra, 2012). Namun, persepsi tersebut mungkin kurang tepat karena KAP big four belum tentu dapat memberikan laporan keuangan yang akurat. Hal ini dikarenakan perusahaan ingin menunjukan kinerja keuangan yang terlihat bagus dimata investor sehingga mengabaikan keberadaan auditor big four dan non big four.

\section{Simpulan}

Berdasarkan analisis data dan hasil pengujian hipotesis pada penelitian ini dapat disimpulkan bahwa likuiditas berpengaruh positif terhadap kualitas informasi laporan keuangan, sedangkan leverage, ukuran perusahaan dan kualitas audit tidak berpengaruh terhadap kualitas laporan keuangan.

Kemampuan persamaan regresi dalam penelitian ini untuk menjelaskan besarnya variasi yang terjadi pada variabel terikat adalah sebesar 46,4\%, sementara 53,6\% dijelaskan oleh variabel lain yang tidak digunakan dalam persamaan regresi ini.

\section{DAFTAR PUSTAKA}

Adiwiratama, Jundan. 2012. Pengaruh Informasi Laba, Arus Kas, dan Size Perusahaan terhadap Return Saham (Studi Empiris pada Perusahaan Manufaktur yang terdaftar di BEI). Skripsi. Universitas Brawijaya. 
Efferin, S., Stevanus Hadi D. dan Yuliawati Tan. 2008. Metode Penelitian Akuntansi. Jakarta: Graha Ilmu.

Fajri, Sri Nurul. 2013. Pengaruh Ukuran Perusahaan, Struktur Kepemilikan dan Konsentrasi Pasar terhadap Kualitas Laporan Keuangan. Artikel Skripsi. Universitas Negeri Padang.

Fanani, Zaenal dkk. 2009. Faktor-faktor Penentu Kualitas Pelaporan Keuangan dan Kepercayaan Investor. Jurnal akuntansi. Universitas Airlangga Surabaya.

Fanani, Zaenal. 2009. Kualitas Pelaporan Keuangan: Berbagai Faktor Penentu dan Konsekuensi Ekonomis. Jurnal Akuntansi dan Keuangan Indonesia. Universitas Airlangga Surabaya.

Fanani, Zaenal. 2010. Analisis Faktor-Faktor Penentu Persistensi Laba. Jurnal Akuntansi dan Keuangan Indonesia. Universitas Airlangga Surabaya.

Financial Accounting Standards Board. 2008. Statement of Financial Accounting Concepts: Objective of Financial Reporting No. 1

Financial Accounting Standards Board. 2008. Statement of Financial Accounting

Concepts: Qualitative Characteristics of Accounting Information No. 2.

Indriani, Rini dan Wahiddatul Khoiriyah. 2010. Pengaruh Kualitas Pelaporan Keuangan terhadap Informasi Asimetri. Simposium Nasional Akuntansi 8 Purwokerto.

Kieso, Donald E., Jerry J. W dan Terry D. W. 2008. Akuntansi Intermediate. Jakarta: Erlangga.
Prena, Gine Das. 2012. Pengaruh Keberadaan Komisaris Independen pada Kecepatan Penyerahan Laporan Keuangan Perusahaan yang Terdaftar Di Bursa Efek Indonesia. Jurnal Riset Akuntansi Universitas Pendidikan Nasional Denpasar.

Ramadhan, Ardiansyah. 2011. Faktor-Faktor Penentu Kualitas Pelaporan Keuangan dan Pengaruhnya terhadap Efisiensi Investasi. Skripsi. Universitas Pembangunan Nasional "Veteran" Jakarta.

Sulistyawati, Nanik. 2010. Pengaruh Rasio Keuangan dan Ukuran Perusahaan terhadap Kinerja pada Perusahaan Daerah Pasar Surya Di Surabaya Periode (2004 - 2008). Skripsi. Universitas Pembangunan Nasional “ Veteran " Jawa Timur.

Sulistyo, Wahyu Adhy Noor. 2010. Analisis Faktor-Faktor yang Berpengaruh terhadap Ketepatan Waktu Penyampaian Laporan Keuangan pada Perusahaan yang Listing Di Bursa Efek Indonesia Periode 2006-2008. Skripsi. Universitas Diponegoro Semarang.

Suriadi. 2009. Pengaruh Ketepatwaktuan Publikasi Laporan Keuangan terhadap Kandungan Kualitas Informasi Laba Akuntansi Pada Perusahaan Perbankan Go Public yang terdaftar di Bursa Efek Indonesia. Skripsi. Universitas Muhammadiyah Yogyakarta.

Udayana, IBN. 2008. Pelatihan Statistik dengan SPSS, V 12.00. Universitas Sarjanawiyata Tamansiswa Yogyakarta. 